\title{
PENINGKATAN LAPISAN PEMAHAMAN KONSEP BANGUN DATAR MAHASISWA CALON GURU DENGAN PENERAPAN MODEL PEMBELAJARAN PRAKTAK
}

\author{
Viktor Sagala ${ }^{1}$, Kusmiyati ${ }^{2}$, Sucipto ${ }^{3}$ \\ ${ }^{1,2,3}$ Universitas Dr. Soetomo Surabaya \\ viktor.sagala@unitomo.ac.id ${ }^{1}$, kusmiyatik@gmail.com², \\ kangsucipto@yahoo.co.id ${ }^{3}$
}

\begin{abstract}
ABSTRAK
Tujuan penelitian ini adalah untuk mendeskripsikan peningkatan lapisan pemahaman konsep bangun datar mahasiswa calon guru dengan menerapkan model pembelajaran praktikumaksiomatik (PRAKTAK). Model pembelajaran PRAKTAK ini masih dalam tahap pengembangan, semetara itu evaluasi dilakukan dengan memanfaatkan model lapisan pemahaman konsep PirieKieren modifikasi yang telah dihipotesiskan tahun 1994 dan dikembangkan oleh para ahli psikologi kognitif sejak 2003 hingga 2017, diantaranya oleh Meel, Manu, Droujkova, Martin, Parameswaran, Walter hingga Sagala. Sebelum penerapan model pembelajaran PRAKTAK, subjek memenuhi lapisan pemahaman keempat (property noticing). Setelah pembelajaran model PRAKTAK, seperangkat soal dikerjakan oleh subjek setelah, kemudian dilakukan wawancara berbasis lembar kerja. Data berupa lembar kerja dan transkrip wawancara dianalisis secara kwalitatif. Hasil analisis menunjukkan bahwa setelah pembelajaran model PRAKTAK lapisan pemahaman subjek meningkat, sehingga memenuhi lapisan keenam (observing).
\end{abstract}

Kata kunci: lapisan pemahaman, pemahaman konsep bangun datar, peningkatan lapisan pemahaman, model pembelajaran PRAKTAK.

\begin{abstract}
The purpose of this study was to describe an increase in the understanding layer of the plane's concept of prospective teacher students by applying a practical-axiomatic learning model (PRAKTAK). This PRAKTAK learning model is still in the development stage, while evaluation is carried out by utilizing a modified model of understanding of the Pirie-Kieren concept that was hypothesized in 1994 and developed by cognitive psychologists from 2003 to 2017, including by Meel, Manu, Droujkova, Martin, Parameswaran, Walter to Sagala. Before the application of the PRAKTAK learning model, the subject fulfills the fourth understanding layer (property noticing). After learning the PRAKTAK model, a set of questions is done by the subject, then the worksheetbased interview is carried out. Data in the form of worksheets and interview transcripts are analyzed qualitatively. The results of the analysis show that after learning the PRAKTAK model the understanding layer of the subject increases, so that it meets the sixth layer (observing).
\end{abstract}

Keywords: understanding layers, understanding of the concept of plane, increasing of understanding layer, PRAKTAK learning model. 


\section{PENDAHULUAN}

Riset ini dilakukan untuk pengembangan model pembelajaran praktikumaksiomatik (PRAKTAK) dan pemanfaatan model lapisan pemahaman PirieKieren Modifikasi. Guru yang professional selayaknya dibekali sejak belajar di Lembaga Pendidikan Tenaga Tependidikan (LPTK). Fakultas Keguruan dan Ilmu Pendidikan (FKIP) Unitomo sebagai lembaga pendidik calon guru berkepentingan mendidik dan menghasilkan guru yang berkompeten. Tujuan riset ini salah satunya untuk pengembangan mutu pembelajaran Geometri. Teori-teori pendidikan dan kognitif yang dihasilkan oleh Piaget, Bruner dan lainnya pada umumnya lahir dari penelitian dengan subjek siswa pendidikan dasar. Pada masa berikutnya, khususnya dua dekade terakhir para peneliti seperti Pirie \& Kieren (1994), Dubinsky (2001), Pegg \&Tall (2005) meneliti subjek siswa SMA bahkan mahasiswa (Sagala, 2016).

Subjek penelitian ini dipilih dari kalangan mahasiswa calon guru Matematika. Model lapisan Pirie-Kieren Modifikasi dimanfaatkan untuk alat penilaian kognitif alternatif. Penelitian lapisan pemahaman ini masih baru dua tahun terakhir ini dikembangkan di Indonesia, setelah Model Pirie-Kieren (1994) yang dihipotesiskan kedua ahli tersebut, kemudian dikembangkan oleh para ahli dan peneliti psikologi kognitif, diantaranya Meel (2003), Manu (2005), Droujkova (2005), Martin (2005), Parameswaran (2010), Sagala (2017) menambahkan dan menyempurnakan indikator-indikator yang awalnya disusun oleh Pirie-Kieren (1994). Sehingga diperoleh Model Lapisan Pemahaman Pirie-Kieren Modifikasi. Model pembelajaran praktikum-aksiomatik (PRAKTAK) merupakan paduan metode praktikum dan metode aksiomatik. Metode praktikum pada umumnya diterapkan dalam pembelajaran sains, sementara metode aksiomatik secara umum dilakukan dalam pembelajaran matematika. Meskipun kurikulum diperbaharui, namun para guru kerap menerapkan metode aksiomatik dalam pembelajaran matematika. Penelitian ini mengembangkan model pembelajaran PRAKTAK dan hasil belajarnya dievaluasi dengan model lapisan pemahaman Pirie-Kieen Modifikasi. Berdasarkan latar belakang tersebut, tujuan dari penelitian ini adalah untuk mendeskripsikan peningkatan lapisan pemahaman konsep bangun datar mahasiswa calon guru dengan penerapan model pembelajaran PRAKTAK 


\section{Peningkatan Lapisan Pemahaman Konsep Bangun Datar Mahasiswa Calon Guru dengan Penerapan Model Pembelajaran PRAKTAK}

Pemahaman konsep matematika seseorang merupakan kemampuan melakukan kegiatan mengabstraksi, mengontruksi dan merepresentasikan konsep tersebut (Sagala, 2017). Teori abstraksi Piaget membedakan tiga macam abstraksi yaitu abstraksi empirik, pseudo-empirik dan reflektif. Abstraksi yang pertama yaitu empirik memperoleh pengetahuan dari sifat-sifat objek. Seorang individu harus melakukan aksi yang sifatnya eksternal terhadap objek melalui abstraksi empirik. Pengetahuan tentang sifat-sifat itu sendiri bersifat internal dan merupakan hasil konstruksi yang dibuat secara internal juga. Selanjutnya dalam abstraksi yang kedua yaitu pseudo-empiric tindakan subjek mulai mengarah kepada ketertarikan kepada sifat-sifat yang dimiliki objek. Abstraksi yang ketiga yaitu reflektif merupakan sebuah konsep yang diperkenalkan oleh Piaget untuk menggambarkan pembangunan struktur logico-matematika oleh seorang individu selama perkembangan kognitif. Dua pengamatan penting yang dilakukan oleh Piaget adalah yang pertama abstraksi reflektif tidak memiliki awal mutlak tetapi hadir di usia yang sangat awal dalam koordinasi struktur sensori-motor (Beth \& Piaget, 1966 dalam Dubinsky \& Mac Donald, 2001) dan kedua, bahwa abstraksi itu secara kontinu berkembang melalui matematika yang lebih tinggi. Representasi adalah model atau bentuk pengganti dari suatu situasi masalah yang digunakan untuk menemukan solusi. Sebagai contoh, suatu masalah dapat direpresentasikan dengan obyek, gambar, kata-kata, atau simbol matematika (Jones \& Knuth, 1991). Menurut Bruner dalam (Tall, 1992) ada tiga bentuk representasi mental, yaitu enaktif (enactive), ikonik (iconic) dan simbolik (symbolic). Teori APOS telah diperkenalkan oleh Dubinsky dalam (Tall,1999) yang menguraikan tentang bagaimana kegiatan mental seorang siswa yang berbentuk aksi (actions), proses (processes), obyek (objects), dan skema (schema) ketika mengkonstruksi konsep matematika. Representasi itu tumbuh secara berurutan dalam individu, mulai dari enaktif, kemudian ikonik dan akhirnya simbolik. Representasi simbolik ini mempunyai kekuatan sendiri yang kemudian kurang bergantung kepada representasi enaktif dan ikonik.

Seorang calon guru matematika seharusnya memiliki lapisan pemahaman yang lengkap, agar kelak menjadi guru yang profesional. Pirie-Kieren (1994) telah 
menghipotesiskan bahwa pemahaman siswa terdiri dari delapan lapisan, yaitu pengetahuan dasar (primitive knowing), pembuatan gambaran (image making), pemilikan gambaran (image having), perhatian sifat-sifat (property noticing), pemformalan (formalizing), pengamatan (observing), penstrukturan (structuring) dan penciptaan (inventising). Model ini telah dikembangkan oleh beberapa ahli psikologi kognitif diantaranya Meel (2003), Manu(2005), Droujkova (2005), Martin (2008), Parameswaran (2010), Sagala (2016) menyempurnakan indikatorindikator yang diawali penyusunannya oleh Pirie-Kieren (Sagala, 2017).

Lapisan pemahaman model Pirie-Kieren itu dapat digambarkan seperti Gambar 1 (Sagala, 2016).

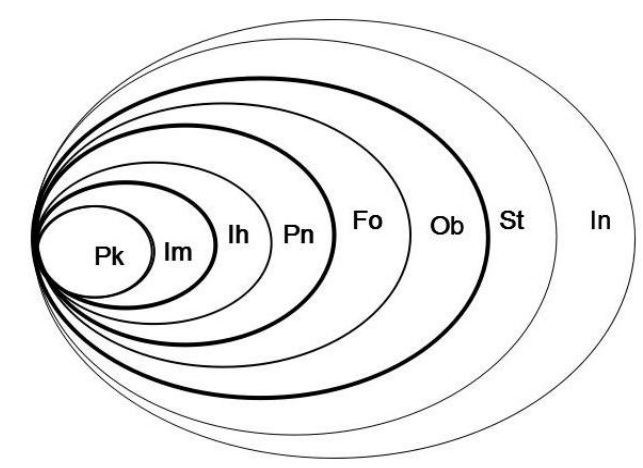

Gambar 1. Lapisan Pemahaman Model Pirie \& Kieren

Keterangan:

$\mathrm{Pk}=$ primitive knowing, $\mathrm{Im}=$ image making, $\mathrm{Ih}=$ image having, $\mathrm{Pn}=$ property noticing, $\mathrm{Fo}=$ formalizing, $\mathrm{Ob}=$ Observing, $\mathrm{St}=$ structuring, $\mathrm{In}=$ inventising .

Indikator setiap lapisan pemahaman diberikan pada Tabel 1.

Tabel 1. Indikator Lapisan Pemahaman Model Pirie-Kieren

\begin{tabular}{llc}
\hline \multicolumn{1}{c}{$\begin{array}{c}\text { Lapisan } \\
\text { Pemahaman }\end{array}$} & \multicolumn{1}{c}{ Indikator Pemahaman } & \multicolumn{1}{c}{ Kode } \\
\hline Primitive Knowing & $\begin{array}{l}\text { Melakukan usaha awal dalam memahami definisi baru } \\
\text { Membawa pengetahuan sebelumnya ke lapisan } \\
\text { pemahaman selanjutnya, }\end{array}$ & $\mathrm{Pk} 1$ \\
& $\begin{array}{l}\text { Melalui aksi yang melibatkan definisi atau } \\
\text { merepresentasikan definisi }\end{array}$ & $\mathrm{Pk} 3$ \\
Image making & $\begin{array}{l}\text { Membuat gambaran berdasarkan pengetahuan } \\
\text { sebelumnya } \\
\text { Mengembangkan ide-ide tertentu } \\
\text { Membuat gambaran suatu konsep melalui gambar } \\
\text { maupun melalui contoh-contoh } \\
\text { Memiliki gambaran mengenai suatu topik }\end{array}$ & $\mathrm{Im} 1$ \\
& & $\mathrm{Im} 2$ \\
& $\mathrm{Im} 3$
\end{tabular}




\begin{tabular}{|c|c|c|}
\hline $\begin{array}{c}\text { Lapisan } \\
\text { Pemahaman }\end{array}$ & Indikator Pemahaman & Kode \\
\hline & $\begin{array}{l}\text { Membuat suatu gambaran mental mengenai suatu topik } \\
\text { tanpa harus mengerjakan contoh-contoh }\end{array}$ & Ih2 \\
\hline \multirow[t]{2}{*}{ Property noticing } & $\begin{array}{l}\text { Mampu mengkombinasikan aspek-aspek dari sebuah } \\
\text { topik untuk membentuk sifat yang relevan dan spesifik }\end{array}$ & Pn1 \\
\hline & $\begin{array}{l}\text { Menyadari kesamaan dan perbedaan beragam gambaran } \\
\text { sebuah topic dan mengembangkannya menjadi sebuah } \\
\text { definisi konsep yang dibangun di antara gambaran- } \\
\text { gambaran tersebut }\end{array}$ & Pn2 \\
\hline \multirow[t]{2}{*}{ Formalising } & $\begin{array}{l}\text { Membuat absatraksi suatu konsep matematika } \\
\text { berdasarkan sifat-sifat yang muncul }\end{array}$ & Fo1 \\
\hline & $\begin{array}{l}\text { Mampu memahami sebuah definisi atau algoritma formal } \\
\text { konsep matematika }\end{array}$ & Fo2 \\
\hline \multirow[t]{4}{*}{ Observing } & $\begin{array}{l}\text { Mampu mengkordinasikan aktivitas formal pada level } \\
\text { sebelumnya sehingga mampu menggunakannya pada } \\
\text { masalah terkait }\end{array}$ & Ob1 \\
\hline & $\begin{array}{l}\text { Mampu mengaitkan pemahaman konsep matematika } \\
\text { dengan struktur pengetahuan baru }\end{array}$ & $\mathrm{Ob} 2$ \\
\hline & $\begin{array}{l}\text { Mampu membuat pernyataan formal tentang suatu } \\
\text { konsep matematika }\end{array}$ & Ob3 \\
\hline & $\begin{array}{l}\text { Mampu mencari suatu pola untuk menentukan suatu } \\
\text { algoritma atau teorema }\end{array}$ & Ob4 \\
\hline \multirow[t]{2}{*}{ Structuring } & $\begin{array}{l}\text { Mampu mengaitkan hubungan antara suatu teorema } \\
\text { dengan teorema lainnya dan mampu membuktikannya } \\
\text { berdasarkan argument logis }\end{array}$ & St1 \\
\hline & $\begin{array}{l}\text { Mampu membuktikan hubungan antara suatu teorema } \\
\text { dengan teorema lainnya secara aksiomatik }\end{array}$ & St2 \\
\hline \multirow[t]{3}{*}{ Inventising } & Memiliki sebuah pemahaman terstruktur komplit & In1 \\
\hline & $\begin{array}{l}\text { Mampu menciptakan pertanyaan-pertanyaan baru yang } \\
\text { dapat tumbuh menjadi sebuah konsep baru }\end{array}$ & In2 \\
\hline & $\begin{array}{l}\text { Mampu menciptakan suatu struktur matematika baru } \\
\text { berdasarkan struktur pengetahuan sebelumnya }\end{array}$ & In3 \\
\hline
\end{tabular}

\section{METODE PENELITIAN}

Metode penelitian yang diterapkan adaah deskriptif-kualitatif. Pengumpulan data diawali dengan tes awal, kemudian dilakukan pembelajaran dengan menerapkan model pembelajaran PRAKTAK, dipilih 1 orang subjek penelitian (Elok), selanjutnya dilakukan wawancara dan transkripsi hasil wawancara. Data-data yang diperoleh dari lembar kerja dan transkrip wawancara selanjutnya dianalisis dengan langkah-langkah kualitatif, yaitu kategorisasi, reduksi, penyajian, penafsiran dan penyimpulan (Moleong, 2010). Subjek penelitian yang terdiri dari mahasiswa calon guru matematika, yaitu mahasiswa semester 2 Program Studi Pendidikan Matematika FKIP Unitomo. Subjek dipilih berdasarkan kemampuan berbicara, sehingga mempermudah mendapatkan data 
wawancara. Pembelajaran PRAKTAK diterapkan kepada mahasiswa dalam satu kelas, demikian juga pemberian tes akhir pembelajaran. Akan tetapi hanya satu orang mahasiswa (Elok) yang dipilih sebagai subjek yang diwawancarai. Instrumen utama dalam penelitian kualitatif ini adalah peneliti sendiri, yaitu mengumpulkan data, menganalisis dan menyimpulkan. Instrumen bantu yang digunakan adalah tes lapisan pemahaman konsep (TLPK) bangun datar dan juga pedoman wawancara. Pembelajaran PRAKTAK sejatinya merupakan paduan antara model pembelajaran praktikum dan aksiomatik. Langkah-langkah pembelajaran dengan metode praktikum menurut Winataputra (2001) sebagai berikut:

\section{Langkah Persiapan}

Persiapan untuk pelaksanaan metode praktikum antara lain menetapkan tujuan, mempersiapkan alat dan bahan yang diperlukan, mempertimbangkan jumlah siswa dengan jumlah alat yang ada dan kapasitas tempat, memperhatikan resiko keamanan, mempersiapkan tata tertib untuk menjaga peralatan dan bahan yang digunakan, membuat petunjuk tentang langkah-langkah yang harus ditempuh selam praktikum berlangsung secara sistematis, termasuk hal-hal yang dilarang atau yang membahayakan.

\section{Langkah Pelaksanaan}

Sebelum siswa melaksanakan praktek, siswa mendiskusikan persiapan dengan guru. Setelah itu mempersiapkan alat-alat atau perlengkapan yang akan digunakan. Selama praktek guru perlu mendekati siswa untuk mengamati proses yang sedang berlangsung. Menerima pertanyaan-pertanyaan, memberikan dorongan dan bantuan terhadap kesulitan-kesulitan yang dihadapi siswa sehingga praktikum dapat dilaksanakan. Selama praktikum, guru hendaknya memperhatikan situasi secara keseluruhan untuk mengontrol praktikum.

\section{Tindak Lanjut}

Setelah praktikum dilakukan, kegiatan selanjutnya adalah meminta siswa membuat laporan untuk diperiksa. Mendiskusikan masalah-masalah yang ditemukan selam praktikum. Memeriksa keberhasilan alat dan menyimpan kembali segala peralatan yang digunakan. 


\section{Peningkatan Lapisan Pemahaman Konsep Bangun Datar Mahasiswa Calon Guru dengan Penerapan Model Pembelajaran PRAKTAK}

Sementara itu, metode aksiomatik merupakan langkah-langkah yang sudah terbiasa dalam belajar matematika, yaitu berdasarkan pernyataaan pangkal, aksioma dilanjutkan dengan definisi, teorema dan hubungan antara teorema. Hal itu dilakukan sesuai dengan hakekat matematika yang objeknya abstrak berupa fakta, konsep, prinsip dan prosedur.

Nur (2011) juga mengatakan bahwa langkah-langkah pembelajaran praktikum adalah mengajukan suatu pertanyaan, mengembangkan hipotesis, merencanakan prosedur, melaksanakan praktikum sesuai prosedur, melakukan interpretasi data dan menarik kesimpulan.

Sementara itu, metode aksiomatik merupakan langkah-langkah yang sudah terbiasa dalam belajar matematika, yaitu berdasarkan pernyataaan pangkal, aksioma dilanjutkan dengan definisi, teorema dan hubungan antara teorema. Hal itu dilakukan sesuai dengan hakekat matematika yang objeknya absatrak berupa fakta, konsep, prinsip dan prosedur.

Berdasarkan uraian tersebut, maka sintaks model pembelajaran PraktikumAsiomatik (PRAKTAK) diberikan pada Tabel 2.

Tabel 2. Sintaks Model Pembelajaran PRAKTAK

\begin{tabular}{|c|c|c|c|}
\hline Tahap & No & Kegiatan Dosen & Kegiatan Mahasiswa \\
\hline \multirow[t]{2}{*}{ Pendahuluan } & 1) & $\begin{array}{l}\text { Menyajikan masalah dan tujuan } \\
\text { pembelajaran }\end{array}$ & $\begin{array}{l}\text { Memperhatikan masalah dan tujuan } \\
\text { yang disajikan }\end{array}$ \\
\hline & 2) & Menyampaian petunjuk praktikum & $\begin{array}{l}\text { Memperhatikan penyampaian } \\
\text { petunjuk praktikum }\end{array}$ \\
\hline \multirow[t]{3}{*}{ Inti } & 3) & $\begin{array}{l}\text { Memfasilitasi, mengamati dan } \\
\text { memberi bimbingan pelaksanaan } \\
\text { praktikum penemuan dan } \\
\text { pembuktian rumus/teorema }\end{array}$ & $\begin{array}{l}\text { melaksanakan praktikum penemuan } \\
\text { dan pembuktian rumus/teorema }\end{array}$ \\
\hline & 4) & $\begin{array}{l}\text { Memfasilitasi, mengamati dan } \\
\text { memberi bimbingan presentasi } \\
\text { hasil pekerjaan praktikum }\end{array}$ & $\begin{array}{l}\text { Melaksanakan presentasi hasil } \\
\text { pekerjaan praktikum }\end{array}$ \\
\hline & 5) & $\begin{array}{l}\text { Melaksanakan pembuktian } \\
\text { rumus/teorema secara aksiomatik } \\
\text { (menjelaskan fakta, konsep, } \\
\text { prinsip, prosedur matematis) }\end{array}$ & $\begin{array}{l}\text { Melaksanakan pembuktian } \\
\text { rumus/teorema secara aksiomatik } \\
\text { (menjelaskan fakta, konsep, prinsip, } \\
\text { prosedur matematis) }\end{array}$ \\
\hline Penutup & 6) & $\begin{array}{l}\text { Bersama mahasiswa melakukan } \\
\text { evaluasi, refleksi/kesimpulan dan } \\
\text { penyampaian tindak lanjut }\end{array}$ & $\begin{array}{l}\text { Bersama dosen malakukan evaluasi } \\
\text { refleksi/kesimpulan dan } \\
\text { penyampaian tindak lanjut }\end{array}$ \\
\hline
\end{tabular}




\section{HASIL PENELITIAN DAN PEMBAHASAN}

Cuplikan lembar kerja subjek diberikan pada Gambar 2.

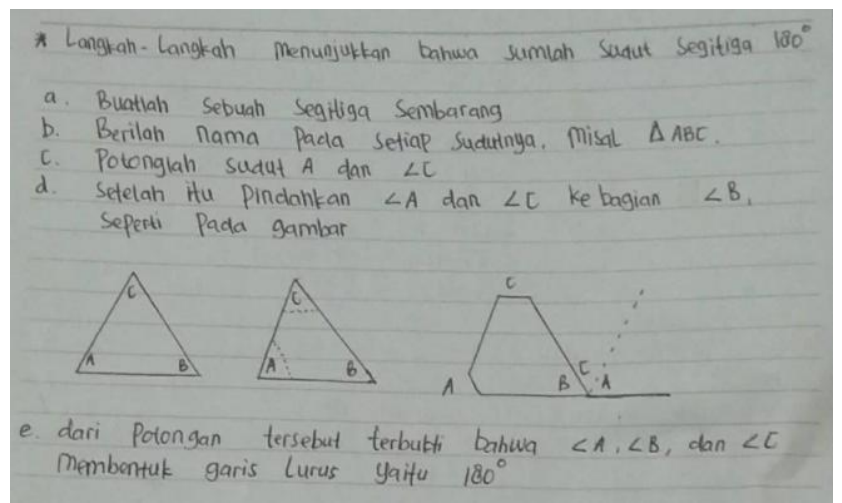

Gambar 2. Lembar kerja TLPK dengan Subjek Jumlah Sudut Segitiga

Dalam wawancara, subjek diberikan beberapa pertanyaan perihal lembar kerja pada Gambar 2, diantaranya; Apa yang diketahui tentang jumlah sudut segitiga? Bagaimana cara menunjukkan bahwa jumlah sudut segitiga adalah seratus delapan puluh derajat? Peralatan apa yang digunakan? Alasan melakukan langkah pembuktian serta kesimpulannya. Subjek menjawab dengan lancar yang menunjukkan bahwa yang bersangkutan melakukan pembuktian jumlah sudut segitiga adalah seratus delapan puluh derajat dengan menggunakan segitiga kertas, gunting, menjelaskan prosedur kerja pembuktian, menjelaskan alasan melakukan langkah pembuktian dan menyimpulkan hasil pembuktian. Hasil dari analisis data setiap bagian konsep disajikan dalam Tabel 3. Adapun dokumentasi aktifitas subjek melakukan kegiatan praktikum dan aksiomatik seperti pada Gambar 3.
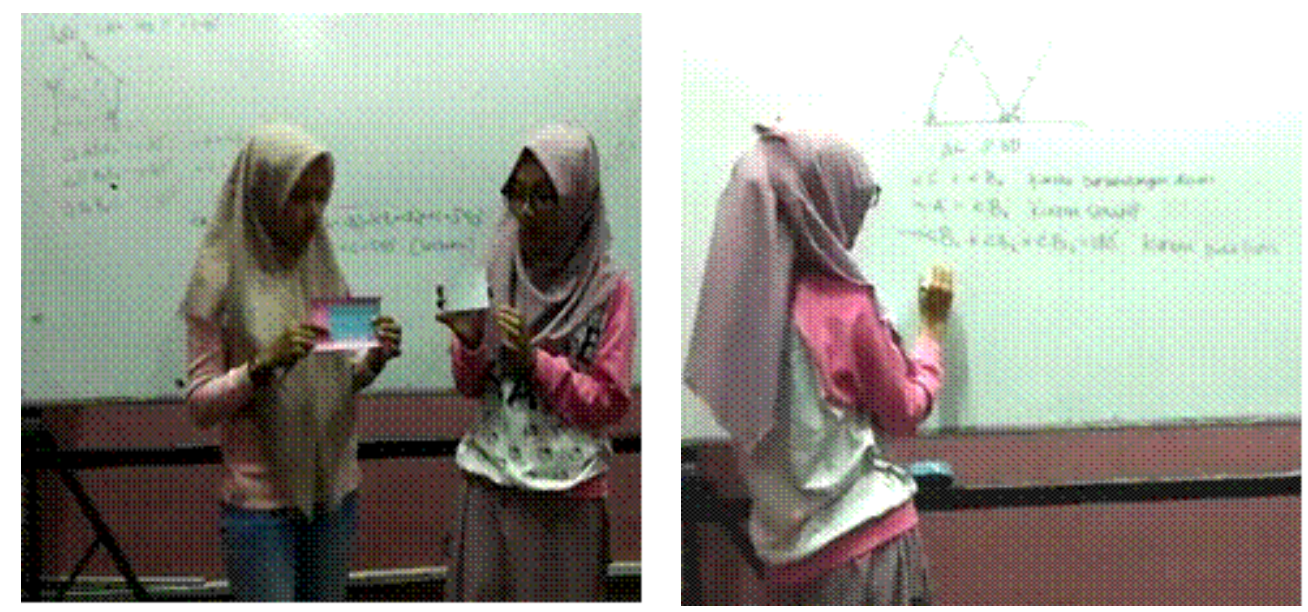

Gambar 3. Kegiatan Praktikum dan Aksiomatik 
Setelah dilakukan klasifikasi serta penafsiran data lembar kerja TLPK, hasil transkrip wawancara, dan dicocokkan dengan indikator-indikator lapisan pemahaman konsep yang telah disusun (Tabel 1), selanjutnya disajikan tabulasi kecocokan pada Tabel 3.

Tabel 3. Indikator Lapisan Pemahaman Konsep yang Dipenuhi Subjek

\begin{tabular}{|c|c|c|c|c|}
\hline Lapisan & Kode & & Indikator Pemahaman & $\begin{array}{c}\text { Indikator Pemeahaman Konsep } \\
\text { Bangun Datar }\end{array}$ \\
\hline \multirow[t]{6}{*}{ 1.Pk } & Pk1 & 1) & $\begin{array}{l}\text { Melakukan usaha awal } \\
\text { dalam memahami definisi } \\
\text { baru }\end{array}$ & $\begin{array}{l}\text { Menyebutkan dan menuliskan jumlah } \\
\text { sudut segitiga } \\
\text { Menyebutkan rumus luas jajar genjang }\end{array}$ \\
\hline & $\mathrm{Pk} 2$ & 2) & $\begin{array}{l}\text { Membawa pengetahuan } \\
\text { sebelumnya ke lapisan }\end{array}$ & $\begin{array}{l}\text { Menyebutkan dan menuliskan jumlah } \\
\text { sudut segilima }\end{array}$ \\
\hline & & & pemahaman selanjutnya, & $\begin{array}{l}\text { Menyebutkan dan menuliskan rumus } \\
\text { luas jajar genjang } \\
\text { Menyebutkan dan menuliskan rumus } \\
\text { luas segitiga }\end{array}$ \\
\hline & $\mathrm{Pk} 3$ & 3) & $\begin{array}{l}\text { Melalui aksi yang } \\
\text { melibatkan definisi atau }\end{array}$ & $\begin{array}{l}\text { Menyebutkan, menuliskan dan } \\
\text { menjelaskan rumus luas jajar genjang }\end{array}$ \\
\hline & & & merepresentasikan definisi & $\begin{array}{l}\text { Menyebutkan, menuliskan dan } \\
\text { menjelaskan jumlah sudut segitiga dan } \\
\text { segi lima }\end{array}$ \\
\hline & & & & $\begin{array}{l}\text { Menyebutkan, menuliskan dan } \\
\text { menjelaskan rumus luas segitiga }\end{array}$ \\
\hline \multirow[t]{5}{*}{ 2.Im } & Im1 & 4) & $\begin{array}{l}\text { Membuat gambaran } \\
\text { berdasarkan pengetahuan } \\
\text { sebelumnya }\end{array}$ & $\begin{array}{l}\text { Menjelaskan jumlah sudut segilima } \\
\text { dalam hubungannya dengan jumlah } \\
\text { sudut segitiga }\end{array}$ \\
\hline & $\operatorname{Im} 2$ & 5) & $\begin{array}{l}\text { Mengembangkan ide-ide } \\
\text { tertentu }\end{array}$ & $\begin{array}{l}\text { Memperkirakan rumus jumlah sudut } \\
\text { segi empat dan segi lima }\end{array}$ \\
\hline & & & & $\begin{array}{l}\text { Menjeaskan hubungan luas persegi } \\
\text { panjang dengan jajar genjang }\end{array}$ \\
\hline & $\operatorname{Im} 3$ & 6) & $\begin{array}{l}\text { Membuat gambaran suatu } \\
\text { konsep melalui gambar }\end{array}$ & $\begin{array}{l}\text { Menggambarkan proses pembuktian } \\
\text { jumlah sudut segitiga }\end{array}$ \\
\hline & & & $\begin{array}{l}\text { maupun melalui contoh- } \\
\text { contoh }\end{array}$ & $\begin{array}{l}\text { Menggambarkan hubungan luas segitiga } \\
\text { dengan jajar genjang }\end{array}$ \\
\hline \multirow[t]{3}{*}{ 3.Ih } & Ih1 & 7) & $\begin{array}{l}\text { Memiliki gambaran } \\
\text { mengenai suatu topik }\end{array}$ & $\begin{array}{l}\text { Menjelaskan proses pembuktian luas } \\
\text { jajar genjang berdasarkan luas persegi } \\
\text { panjang }\end{array}$ \\
\hline & & & & $\begin{array}{l}\text { Menjelaskan proses pembuktian luas } \\
\text { segi tiga berdasarkan luas segi empat }\end{array}$ \\
\hline & Ih2 & 8) & $\begin{array}{l}\text { Membuat suatu gambaran } \\
\text { mental mengenai suatu } \\
\text { topik tanpa harus } \\
\text { mengerjakan contoh- } \\
\text { contoh }\end{array}$ & $\begin{array}{l}\text { Menjelaskan pembuktian melalui } \\
\text { praktikum jumlah sudut segitiga, sudut } \\
\text { segilima, luas jajar genjang, luas } \\
\text { segitiga secara umum. }\end{array}$ \\
\hline \multirow[t]{2}{*}{ 4.Pn } & Pn1 & 9) & $\begin{array}{l}\text { Mampu } \\
\text { mengkombinasikan aspek- } \\
\text { aspek dari sebuah topik } \\
\text { untuk membentuk sifat } \\
\text { yang relevan dan spesifik }\end{array}$ & $\begin{array}{l}\text { Menghubungkan pembuktian melalui } \\
\text { praktikum dengan pembuktian melalui } \\
\text { gambar-gambar dan pembuktian tanpa } \\
\text { praktikum }\end{array}$ \\
\hline & $\operatorname{Pn} 2$ & 10) & $\begin{array}{l}\text { Menyadari kesamaan dan } \\
\text { perbedaan beragam }\end{array}$ & $\begin{array}{l}\text { Menghubungkan luas persegi panjang, } \\
\text { jajar genjang, segitiga dan lingkaran }\end{array}$ \\
\hline
\end{tabular}




\begin{tabular}{|c|c|c|c|c|}
\hline Lapisan & Kode & & Indikator Pemahaman & $\begin{array}{c}\text { Indikator Pemeahaman Konsep } \\
\text { Bangun Datar }\end{array}$ \\
\hline \multirow{3}{*}{ 5.Fo } & & & $\begin{array}{l}\text { gambaran sebuah topic dan } \\
\text { mengembangkannya } \\
\text { menjadi sebuah definisi } \\
\text { konsep yang dibangun di } \\
\text { antara gambaran-gambaran } \\
\text { tersebut }\end{array}$ & $\begin{array}{l}\text { antara pembuktian dengan praktikum } \\
\text { dengan aksiomatik, sehingga } \\
\text { menemukan pola hubungan secara } \\
\text { aksiomatik }\end{array}$ \\
\hline & Fo1 & 11) & $\begin{array}{l}\text { Membuat absatraksi suatu } \\
\text { konsep matematika } \\
\text { berdasarkan sifat-sifat yang } \\
\text { muncul }\end{array}$ & $\begin{array}{l}\text { Menjelaskan secara khusus konsep } \\
\text { jumlah sudut segit tiga } \\
\text { Menjelaskan secara umum luas persegi } \\
\text { panjang, segitiga, lingkaran }\end{array}$ \\
\hline & Fo2 & 12) & $\begin{array}{l}\text { Mampu memahami sebuah } \\
\text { definisi atau algoritma } \\
\text { formal konsep matematika }\end{array}$ & $\begin{array}{l}\text { Menjelaskan secara rinci dan procedural } \\
\text { pembuktian jumlah luas sudut segi tiga, } \\
\text { jajar genjang, luas jajar genjang, segi } \\
\text { tiga dan juga lingkaran }\end{array}$ \\
\hline \multirow[t]{4}{*}{$6 . \mathrm{Ob}$} & Ob1 & 13) & $\begin{array}{l}\text { Mampu mengkordinasikan } \\
\text { aktivitas formal pada level } \\
\text { sebelumnya sehingga } \\
\text { mampu menggunakannya } \\
\text { pada masalah terkait }\end{array}$ & $\begin{array}{l}\text { Membuktika secara aksioatik formal } \\
\text { jumlah sudut segitiga dan segi lima, } \\
\text { membuktikan dan menemukan rumus } \\
\text { luas jajar genjang, segitiga. lingkaran }\end{array}$ \\
\hline & $\mathrm{Ob} 2$ & 14) & $\begin{array}{l}\text { Mampu mengaitkan } \\
\text { pemahaman konsep } \\
\text { matematika dengan } \\
\text { struktur pengetahuan baru }\end{array}$ & $\begin{array}{l}\text { Membuktikan rumus luas lingkaran dan } \\
\text { hubungannnya dengan luas jajar } \\
\text { genjang }\end{array}$ \\
\hline & Ob3 & 15) & $\begin{array}{l}\text { Mampu membuat } \\
\text { pernyataan formal tentang } \\
\text { suatu konsep matematika }\end{array}$ & $\begin{array}{l}\text { Menjelaskan pemahaman formal dalam } \\
\text { bentuk peryatan sikap dan orasi ilmiah } \\
\text { matematis }\end{array}$ \\
\hline & $\mathrm{Ob} 4$ & 16) & $\begin{array}{l}\text { Mampu mencari suatu pola } \\
\text { untuk menentukan suatu } \\
\text { algoritma atau teorema }\end{array}$ & $\begin{array}{l}\text { Membuktikan rumus luas lingkaran } \\
\text { dengan menghubungkannya dengan } \\
\text { konsep segi empat, jajar genjang dan } \\
\text { persegi panjang }\end{array}$ \\
\hline
\end{tabular}

Berdasarkan Tabel 3, terlihat bahwa setelah pembelajaran PRAKTAK subjek memenuhi indikator Pk1, Pk2, Pk3, Im1, Im2, Im3, Ih1, Ih2, dan Pn1, Pn2, Fo1, Fo2, dan Ob1, Ob2, Ob3 dan Ob4, semuanya ada 16 indikator. Subjek memenuhi lapisan ke-6 yaitu Observing. Sementara, sebelum pembelajaran subjek memenuhi 10 indikator yaitu Pk1, Pk2, Pk3, Im1, Im2, Im3, Ih1, Ih2, Pn1 dan Pn2, subjek memenuhi lapisan Property Noticing. Lapisan pemahaman subjek belum mencapai structuring dan inventising. Gambar lapisan pemahaman konsep bangun datar yang dipenuhi oleh subjek diberikan pada Gambar 5 dan 6.

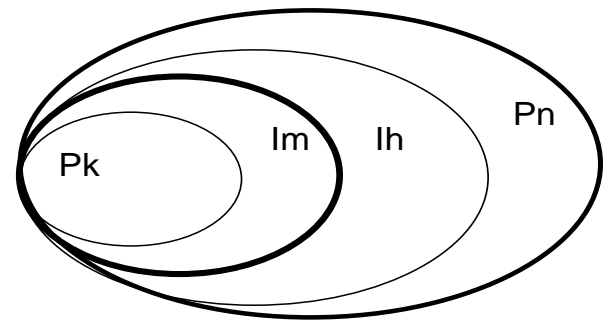

Gambar 5. Lapisan Pemahaman Konsep Bangun Datar Sebelum Pembelajaran PRAKTAK 


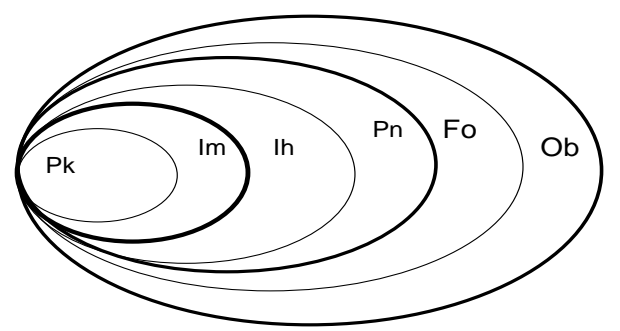

Gambar 6. Lapisan Pemahaman Konsep Bangun Datar Setelah Pembelajaran PRAKTAK

Lapisan pemahaman konsep bangun datar yang dipenuhi subjek mahasiswa calon guru pada awalnya adalah primitive knowing, image making, image having, property noticing. Selanjutnya setelah penerapan model pembelajaran PRAKTAK, lapisan pemahaman konsep bangun datar yang dipenuhi subjek mahasiswa calon guru pada akhirnya adalah primitive knowing, image making, image having, property noticing, dilanjutkan dengan formalizing dan observing. Dalam hal ini ada peningkatan (primitive knowing) ke lapisan keenam (observing) setelah penerapan pembelajaran PRAKTAK. Temuan penelitian ini berbeda dengan hasil penelitian Sagala (2016) dimana disimpulkan bahwa subjek perempuan dan laki-laki mahasiswa semester 4 berkemampuan matematika tinggi memenuhi lapisan ketujuh (Structuring) dan satu indikator lapisan kedelapan (Inventising), sehingga disebut memenuhi lapisan oida inventising (inventisingoid). Temuan penelitian ini juga berbeda dengan hasil penelitian Sagala (2017) yang menyimpulkan bahwa subjek mahasiswa semester 4 memenuhi lapisan ketujuh (Structuring) menuju lapisan kedelapan (Inventising).

Perbedaan ini mungkin disebabkan peningkatan kemampuan kognitif mahasiswa dari semester dua ke semester empat. Peningkatan seperti ini diharapkan berlangsung terus hingga menyelesaikan perkuliahan, sehingga berpotensi menjadi guru yang professional. Perbedaan penting penelitian inni dibandingkan dengan penelitian sebelumnya adalah penerapan pembelajaran PRAKTAK dalam upaya meningkatkan lapisan pemahaman. Penelitian sebelumnya adalah perihal profil lapisan pemahaman tanpa mengaitkannya dengan pembelajaran. Oleh sebab itu penelitian tentang peningkatan lapisan 
pemahaman dengan menerapkan model pembelajaran tertentu masih penting dilakukan.

\section{SIMPULAN}

Pada awalnya pemahaman konsep bangun datar mahasiswa calon guru memenuhi lapisan keempat (property noticing), kemudian setelah penerapan model pembelajaran PRAKTAK, subjek memenuhi lapisan keenam (observing), dengan demikian ada peningkatan.

\section{DAFTAR PUSTAKA}

Droujkova, A., Berenson, B., Slaten, K. \& Tombes, S. (2011) "A Conceptual Framework for Studying Teacher Preparation: The Piere-Kieren Model, Collective Understanding and Metafor". Proceeding of the 29th Conference of the International Group for the Mathematical Education. Volume 2:289-296.

Dubinsky, E \& Wilson, R. (2013) "High School Students' Understanding of the Function Concept". the Journal of Mathematical Behavior 32 (2013) 83 101. For a pre-publication draft PDF, http://www.sciencedirect.com/science/article/pii/S0732312312000582.

Jones, B. F., \& Knuth, R. A. (1991). What does Research Say about Mathematics? [on-line]. Available: http://www. ncrl.org/sdrs/areas/stw_esys/2math.html.

Manu. (2005) Language Switching and Mathematical Understanding in Tongan Classrooms: An Investigation.Journal of Educational Studies.Vol 27, Nomor 2, diakses 6 Maret 2015.

Martin, L. C. (2008) Folding back and the dynamical growth of mathematical understanding: Elaborating the Pirie-Kieren Theory The Journal of Mathematical Behavior, 2008-Elsevier Volume 27, Issue 1, 2008, Pages 64-85 Online diakses 28 Agustus 2018.

Meel, D. E. (2003) Model and Theories of Mathematical Understanding: Comparing Piere-Kieren's Model of the Growth of Mathematical Understanding and APOS Theory. CMBS Issues in Mathematical Education.Volume 12, 2003.

Moleong, J. (2010) Metodologi Penelitian Kualitatif. Edisi Revisi. Bandung. PT Remaja Rosdakarya.

Nur, M. (2011) Ketrampilan-ketrampilan Proses Sains, Pusat Sains dan Matematika Sekolah UNESA.

Parameswaran, R. (2010) Expert Mathematicians Approach to Understanding Definition, The Mathematic Educator Vol 20, Number I:45-51.

Pegg, J. \& Tall, D. (2005) The fundamental cycle of concept construction underlying various theoretical frameworks, Proceedings of PMEVolume 37, Issue $6, \quad$ pp $468-475$ Online http://link.springer.com/article/10.1007/BF02655855\#page-2. 
Piere, S. \& Kieren, T. (1994) Growth in Mathematical Understanding: How we Can Characterize it an How can Represent it. Education Studies in Mathematics, 9, 160-190.

Sagala, V. (2016) Profil Lapisan Pemahaman Konsep Turunan Fungsi dan Bentuk Folding Back Mahasiswa Calon Guru Berkemampuan Matematika Tinggi Berdasarkan Gender, MUST: Journal of Mathematics Education Vol 1, No 2 (2016) http://www.jurnal.unsyiah.ac.id/DM/article/view/8384

Sagala, V. (2017) STRUKTUR LAPISAN PEMAHAMAN KONSEP TURUNAN FUNGSI MAHASISWA CALON GURU MATEMATIKA Jurnal Didaktik Matematika ISSN 2355-4185 (print) | 2548-8546 (online) http://jurnal.unsyiah.ac.id/DM.

Tall, David. 1993. The Transition from Arithmetics to Algebra: Numbers Patterns of Proceptual Programming? New Directions in Algebra Education, Queensland University of Teachnology, Brisbane, 213-231.

Tall, David. 1999. "Reflections on APOS theory in Elementary and Advanced Mathematical Thinking”. Presented at PME23, Haifa, Israel. Vol 1, 111118. http://www.warwick.ac.uk/staff/ David. Tall/pdfs/dot1999c-apos-inamt-pme.pdf. Diakses tanggal 30 Juni 2018.

Winataputra, Udin S. (2001) Strategi Belajar Mengajar IPA, Jakarta: Universitas Terbuka. 